those to the rectum below the level of the posterior vaginal vault or upper border of the prostate. Each group is separated into those done for malignant and for non-malignant conditions. Overall nine anastomoses have leaked $(2 \cdot 25 \%)$. A leak is considered to have occurred when obvious faeces appear through a drain or the abdominal wall, and whenever there is any evidence of perianastomotic induration. Endoscopic or barium examinations have not been carried out as a routine but have been done only when a leak has been suspected before restoring continuity of the colostomy performed to relieve the leaking anastomosis.

Anastomoses have been felt digitally or seen endoscopically or by barium contrast in 20 cases. The suture line is difficult to detect by these investigations. At postmortem examination 41 anastomoses have been seen to be a thin line, easily distensible and mobile. Seven anastomoses have been examined at later laparotomy and detected only by the silk or nylon (black) stitches. Two strictures have occurred, needing a further resection. In nine cases there were pre-existing colostomies; in none of these were there leaks.

Inpatient stays after operation have varied from 11 to 15 days except in cases with leaks or other major complications.

A E CARTER

Ealing Hospital,

Southall, Middx UB1 3EU

\section{Pseudomembranous colitis after treatment with metronidazole}

SIR,-Dr Robin P Bolton advocates the use of metronidazole for the treatment of pseudomembranous colitis ( $25 \mathrm{July}, \mathrm{p} 311$ ), in support of which he quotes a study of metronidazole in antibiotic-induced diarrhoea. Although this condition forms part of a spectrum of disease with pseudomembranous colitis, it does not necessarily follow that metronidazole is suitable therapy for the more severely ill patient with the latter problem.

In our experience ${ }^{2}$ metronidazole failed to control pseudomembranous colitis in the only patient so treated, with fatal consequences. Since 1978, when the value of vancomycin in pseudomembranous colitis was established, ${ }^{3}$ it has been our policy to prescribe vancomycin in all such patients. So far six patients have been successfully treated, although six relapses were subsequently encountered in four of them. ${ }^{2}$ Contrary to Dr Bolton's assertions, the value of metronidazole in the management of pseudomembranous colitis has not been formally assessed. Because of the potential morbidity and mortality associated with this condition, it would seem prudent to use vancomycin until the role of metronidazole is established.

\section{R PENNINGTON}

King's Cross Hospital,
Dundee DD3 8EA

1 Bolton RP. Gut 1980;21:A921. Ritchie PH, Pennington CR. Scot Med f 1980;25:
278-80.

Keighley MRB, Burden BW, Arabi Y, et al. Br Med $\mathcal{F}$ 1978;ii:1667-9.

\section{Foodborne gastroenteritis of unknown aetiology: a virus infection?}

SIR,-There are many viruses which may be found in the stools of patients with gastroenteritis: rotavirus, Norwalk-like viruses, adenovirus, astrovirus, calicivirus, and coronavirus-like particles. ${ }^{1}$ It is unclear which or how many of these viruses can be foodborne.

Electron microscopy and tissue-culture techniques failed to detect viruses in stools from 14 outbreaks of non-bacterial foodborne gastroenteritis (30 May, p 1801). The particles seen nfter extraction and concentration with caesium chloride were $23-26 \mathrm{~nm}$ in diameter with a density of $1.40 \mathrm{~g} / \mathrm{cm}^{3}$. Dr Hazel Appleton and others implied that the agent was not a Norwalk virus, because maximum excretion of the particles occurred on days 4-6, while the Norwalk virus is normally excreted during the first 48 hours; the particies were, however, of the same shape, size, and density (caesium chloride) as the Norwalk virus. Another study has shown that Norwalk virus is detectable by immunoelectron microscopy in stools up to 72 hours after the onset of illness." This technique is valuable for the recognition of viruses, such as Norwalk virus, which do not replicate in cell culture or which are present in small numbers.

Other viruses of unknown affiliation have been associated with gastroenteritis. They have been named: Hawaii, Montgomery County, Ditchling, and $\mathrm{W}$ agent. Although the number of antigenically distinct strains is unclear, there are at least three serotypes of Norwalk virus. A recent review ${ }^{3}$ compared the characteristics of Norwalk virus with rotavirus, but the differences between other viruses are less clear. Until a variety of cheaper and less complex techniques becomes available, the properties of new isolates and the aetiology of viral gastroenteritis will remain unresolved.

\section{JOHN CARSON}

\section{University Department of \\ Biology,
Bradford BD7 1I)P}

${ }^{1}$ Holmes IH. Prog Med Virol 1979;25:1-36. Thornhill TS, Kalica AR, Wyatt RG, Kapikian AZ, Chanock RM. F Infect Dis 1975;132:28-34 Blacklow NR, (iukor G. N Engl f Med $1981 ; 304$ :
397-406.

\section{Benign familial tremor treated with primidone}

SIR,-Dr M D O'Brien and his colleagues (17 January, p 178) report their results in the treatment of benign familial tremor with primidone. On the basis of the pharmacokinetic data on two patients they conclude that one of the two active metabolites of primidone, phenylethylmalonamide, would be effective while phenobarbitone would not have any effect on tremor. On the basis of our experience we suggest a different evaluation of these data.

Before the advent of propranolol barbiturates were the suggested drugs for the medical treatment of essential tremor, though controlled clinical trials have never been performed so far as we know. So we first planned a dose-response study for phenobarbitone. ${ }^{1}$ Twenty-four patients (five women, 19 men) with postural tremor were treated with phenobarbitone. Tremor was evaluated both clinically and instrumentally by means of a linear accelerometer. Each patient was evaluated before therapy and subsequently about once a month. The duration of the study ranged from three to 16 months (mean SD $8 \cdot 7 \cdot 3 \cdot 6$ ). The dose with the best effects on symptoms and no unwanted ones was $1.3+0.4 \mathrm{mg} / \mathrm{kg}$ (mean $\mathrm{SD}$ ), with corresponding plasma levels of $13 \mathrm{mg} / \mathrm{l}$ (range $8-20 \mathrm{mg} / \mathrm{l}$ ). During the study tremor frequency did not change, but amplitude showed a marked reduction from a mean of $0.97 \div 1.17 \mathrm{~g}$ before treatment to $0.34+0.46 \mathrm{~g}$ during phenobarbitone treatment $\left(g=9.8 \mathrm{~m} / \mathrm{s}^{2}\right)$. The clinical evaluation showed a similar improvement in tremor amplitude. Nineteen patients out of 24 reported subjective benefit, and the effects lasted with no change after many months of therapy.
Our second stup was to undertake a controlled trial to compare phenobarbitone and propranolol treatments with placebo. A double-blind cross-over study with a Latin square design was chosen (the complete results are to be published shortly). Twelve patients (six women, six men) with previously untreated essential tremor and no other neurological abnormality entered the trial. Subjective, clinical, and instrumental evaluation of tremor were carried out. Standard oral doses of propranolol (about $1.7 \mathrm{mg} / \mathrm{kg}$, as recommended by many authors ${ }^{2-5}$ ) and phenobarbitone (about $1.3 \mathrm{mg} / \mathrm{kg}$, on the basis of our previous study) were used.

Accelerometric data showed a notable reduction in tremor amplitude during treatments by comparison with baseline values: about $34 \%$ with placebo (NS) and more than 50". with propranolol and phenobarbitone $(p<0.05)$. Six patients preferred phenobarbitone, six propranolol, and none placebo. Side effects were minimal and only one patient dropped out because of them-while on propranolol, because of excessive bradycardia.

As our studies confirm the efficacy of phenobarbitone for essential tremor, the role of phenobarbitone in the work of Dr O'Brien and his colleagues might be reassessed. Substituting phenobarbitone for primidone, they used $90 \mathrm{mg}$ of phenobarbitone daily, a dose that seems inadequate to maintain the previous phenobarbitone plasma levels, obtained with 750 and $1000 \mathrm{mg}$ of primidone daily, ${ }^{6}$ so that worsening of tremor may be also explained by decreased phenobarbitone plasma levels. When they abruptly substituted phenylethylmalonamide for primidone for three days, the same effect was maintained, while subsequent withdrawal of phenylethylmalonamide was followed by a marked increase in tremor amplitude during the next 96 hours. Again, we suggest that this could at least in part be due to the fall in plasma phenobarbitone levels. Even if the restarting of treatment with phenylethylmalonamide produces impressive improvement, confirming the relative efficacy of phenylethylmalonamide, one cannot exclude the possible importance of a placebo effect.

In conclusion, even if further studies seem necessary to elucidate further the role of primidone and its main metabolites in the control of tremor amplitude, our experience suggests that phenobarbitone itself has a definite and important efficacy.

Gaetano Procaccianti Paolo Martinell Agostino BARUZzI Paolo Pazzaglia Elio Lugaresi

Institute of Neurology,
University of Bologna,

University of Bologna,
40123 Bologna, Italy ${ }^{1}$ Pazzaglia P, Baruzzi A, Martinelli P, et al. Atti $1-12$.

2 Dupont E, Hansen HJ, Dalby MA. Acta Neurol Scand 1973;49:75-84.

Tolosa ES, Loewenson RB. Neurology (Minneap) $1975 ; 25: 1041-4$

Teravainen H, Fogelholm R, Larsen A. Neurology (Minneap) 1976;26:27-30.

Jefferson D, Jenner P, Marsden CD. F Neurol Neurosurg Psychiatry 1979;42:831-7.

Eadie MJ, Tyrer JH. Anticonvulsant therapy. Pharmacological basis and practice. 2nd ed.
Edinburgh: Churchill Livingstone, 1980:190-7

\section{Poliomyelitis serosurveillance in adolescent population}

SIR,-With a gradual improvement in the socioeconomic status of the developing countries and a drastic reduction in poliomyelitis incidence in the developed world, it is essential that the adolescent population should be regularly screened for poliovirus antibody levels to ensure that the number of triple 